\title{
Corrigendum: Quantitative efficiency assessment based on the dynamic slack-based network data envelopment analysis for commercial banks in Ghana
}

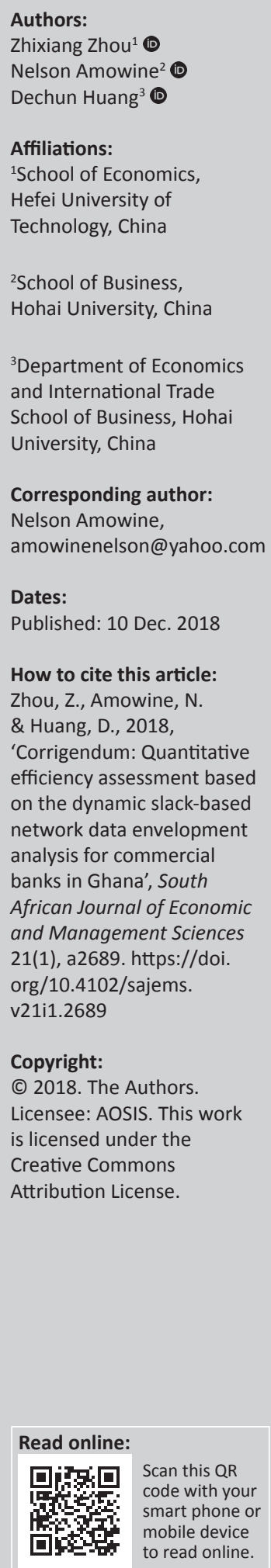

Published: 10 Dec. 2018

How to cite this article: Zhou, Z., Amowine, N. \& Huang, D., 2018,

'Corrigendum: Quantitative efficiency assessment based on the dynamic slack-based network data envelopment analysis for commercial banks in Ghana', South African Journal of Economic and Management Sciences 21(1), a2689. https://doi. org/10.4102/sajems. v21i1.2689

\section{Copyright:}

(C) 2018. The Authors. Licensee: AOSIS. This work is licensed under the Creative Commons Attribution License.

In the initial published version of this article, Nelson Amowine's affiliation was incorrectly displayed. His correct affiliation is the School of Business, Hohai University, China. The error has been corrected in the PDF version of the article. The author apologises for any inconvenience that this omission may have caused. 